\title{
The 2018 Recruitment and Selection of Civil Servants In Indonesia: Problems and Solutions
}

\author{
Ismiati Nur Istiqomah ${ }^{1}$, Atika Indah Nur Atsarina ${ }^{2}$ \\ ${ }^{1}$ Mahasiswa Pasca Sarjana Manajemen dan Kebijakan Publik, FISIPOL UGM (email: akuistiqomah@gmail.com), \\ ${ }^{2}$ Mahasiswa Pasca Sarjana Manajemen dan Kebijakan Publik, FISIPOL UGM (email: atikaatsarina@gmail.com)
}

\begin{abstract}
Recruitment and selection of civil servant is an effort of the Government of Indonesia to get a competent civil servants. The 2018 recruitment and selection of civil servant process was using merit system that is conducted online. But in its implementation, there are still many problems found at the Ministries / Institutions and Regional Government levels. This article discusses the issues in the 2018 recruitment and selection of civil servant process, and how ideally the process is supposed to be carried out. The method used in this article is literature review, both from journal articles, news articles, and other data that support research. The findings of the study show that the implementation of the 2018 recruitment and selection of civil servant still leaves some problems. But in this article, authors focuses on problems that are not getting much attention from many parties, such as the lack of attention from government to the needs of employees with future potential, and the subjectivity of the selectors in the interview process. The researcher recommends that the government needs to apply the concept of future potential skills in recruiting prospective civil servants and blind interviews to recruit a competent candidates. This article has limitations because it only uses literature review methods so it is necessary to do an actual research in order to produce research that is closer to the actual reality.
\end{abstract}

\section{Keywords:}

the 2018 civil servants recruitment and selection; future potential skills; blind interviews

\section{Introduction}

In this article, the author will focus on evaluating the implementation of Recruitment and Selection of civil servants (CPNS) of the Republic of Indonesia for Fiscal Year 2018. The author will describe some of the problems in the recruitment and selection process, and how the standard of a recruitment and selection process is carried out based on literature that already exists.

In an organization, both public and private, the existence of human resources is the most crucial factor, because human resources play a large role and have control over other 
resources. The better thehuman resources that existing in the organization, the better the quality of organizational performance. To get good human resources (HR), an organization needs to carry out a good recruitment and selection. Recruitment and selection are steps to find, choose, and attract human resources who have the characteristics that needed by the organization (Osoian \& Zaharie, 2014). The employee recruitment process is an important step to achieving quality human resources (Breaugh \& Starke, 2000). Besides, recruitment and selection is the main gate to advance organizational performance, so that the organization can achieve itgoals.

To get a good quality human resources, changes are needed in the employee recruitment and selection process. By making changes to the recruitment and selection process, organizations can strengthen their competitiveness in the labor market. Changes that needed to be done are, include; procedural changes namely simplifying and legalizing the application process for prospective workers; improvement in the recruitment and selection process which is a fundamental improvement in human resource management (HRM) and the use of technology in recruitment and selection (Lavigna \& Hays, 2004).

Recruitment and selection procedures between public organizations differ from private organizations (Zhang, Xu, \& Zhang, 2015). Recruitment and selection in public organizations are more formal. Besides, the time needed by public organizations in the recruitment process also tends to be longer than private organizations. Recruitment and selection in public organizations often take several months to complete, whereas recruitment and selection of employees in private organizations only require days (Zhang, Xu, \& Zhang, 2015).

HR control arrangements that are centralized and enforce many rigid rules are often inhibit and weaken the potential of employees. One of the most positive developments in contemporary HRM is reducing reliance on control activities. One way to reduce dependence on control activities is through decentralization reform. Decentralization reform can give regional governments broad powers to regulate human resource management policies in their regions (Ishii, Rohitarachoon, \& Hossai, 2013).

Besides that, the last change is the use of technology. For job applicants, the existence of technology helps to make it easier for prospective applicants to see job vacancies, due to a large number of job vacancies advertised via digital. By using technology and several filters, 
we get to know the candidate's profile very well before the first interview (Mirela \& Voicu, 2014).

If an organization does not use new techniques in the recruitment and selection process, it will be left behind by other organizations. However, in the adoption of a new recruitment and selection strategy, it must be adapted to the conditions of each organization (Lavigna \& Hays, 2004). Public organizations are often influenced by the principle of equality, relying more on collectivist and egalitarian values than private organizations (Ozbilgin \& Tatli, 2011).These traditional public sector values require that all employees should be treated equally and accept the same opportunities to growth (Boselie \& Thunnissen, 2015).

In the process of the 2018 Recruitment and Selection for civil servant in Indonesia, the enthusiasm of the Indonesian people is very high. Noted by the number of applicants reached 2,572,891 people (Arnani, Kompas.com, 2018). The high enthusiasm of the people is none other than the believes that working in the public sector, especially in government, provides a more secure future guarantee. Wages and benefits received are the first factors considered by prospective employees in the public sector. The benefits of working in the public sector, in this case, as a civil servants in Indonesia, are considered to be far better than the private sector (Berman, Bowman, West, \& Wart, 2010). In Indonesia, a civil servant will still get paid even though the employee has retired, or commonly called a pension fund. Besides, several other reasons on why the public sector is way more interestingfor a prospective employees are, including (Education Development Center, 2002):

1. To make a difference in various leadership positions in the non-profit sector; different branches of the local and central government and the international arena;

2. To be intellectually involved in the challenges facing their community;

3. To build a career and personal development skills that they can use throughout their lives;

4. To build a better future;

5. To build communication networks with different communities; and

6. To get a sense of responsibility towards others and things that are a common concern. 
To implemented the recruitment and selection civil servant in Indonesia, the Government implements a merit system. This merit-based system emphasizes technical qualifications using processes that analyze work competence and emphasizes application procedures transparently. The merit system requires a series of tests to review work experience, performance evaluations or recommendations, and written tests (Berman, Bowman, West, \& Wart, 2010). Merit-based selection is usually used in the recruitment and selection of non-executive positions. The merit system will provide fairness to competing candidates for employees, and guarantee the minimum competencies and qualifications that prospective employees must-have.

In Indonesia, in 2018, the Government of Indonesia held the largest recruitment and selection of civil servant throughout Indonesia's history, with a quota reaching 238,015 formations. The government carries out national recruitment and selection with an onlinebased merit system through the sscn.bkn.go.id portal. Recruitment and selection of client systems have great advantages, because online systems can reach prospective employees more widely with minimal costs, and tend to be easier to reach (Berman, Bowman, West, \& Wart, 2010) prospective employees throughout Indonesia. Data from the Merit System Protection Board (MSPB), shows that the online system in recruitment is the second most influential method after the recruitment method by the network of friends or relatives (Merit System Protection Board (MSPB), 2008).

In the 2018's Recruitment and Selection of Civil Servant selection process, there are three stages of selection that must be passed by prospective employees, namely: Administration Selection with an elimination model; Basic Competency Selection (Seleksi Kompetensi Dasar-SKD) with a Computer Assisted Test (CAT) system; and Field Competency Selection (Seleksi Kompetensi Bidang-SKB). In its implementation, the Government of Indonesia through the Badan Kepegawaian Negara (BKN) claims that the implementation of recruitment and selection of CPNS FY 2018 has been carefully prepared and was running well. However, some findings in the field, tells that the recruitment and selection process of Civil Servant 2018 are still experiencing some problems. In terms of employee recruitment, the problems that are often faced come from three forms, namely: constraints that originate from the organization concerned; the obstacles of the prospective employees themselves; 
and external factors constraints originating from the environment in which the organization operates (Sunyoto, 2012).

In carrying out the selection and recruitment process in public organizations, organizations often have difficulty in determining the right candidate given that many candidates are available but only a few are qualified according to organizational standards. Yet to form a good public organization also requires good employees (Lavigna \& Hays, 2004). So far, public organizations are often less competitive in recruiting competent employees than private organizations. In the recruitment and selection process of private organizations, they will put forward high-quality standards for prospective employees to get the best candidates. Indeed, in the 2018 recruitment and selection of Civil Servant, the government has set a passing grade, but in the course of the selection process, the government actually reduced the passing grade because many participants did not reach the passing grade limit that had been determined in the selection process at the Basic Competency Selection (Seleksi Kompetensi Dasar-SKD).

Among the problems that were most complained (according the research results of the researcher while interview with 5 participant recruitment and CPNS selection 2018) about in the 2018 recruitment and selection process of Civil Servant were related to the changes in the selected schedule that were uncertain. However, in this paper, the researcher detected several problems that were less of a public concern, including government policies through the Minister of Administrative Reform and Bureaucratic Reform (Menpan RB) who decided to reduce the passing grade threshold after the Basic Competency Selection (Seleksi Kompetensi Dasar-SKD) test was held because the number of candidates who do not pass the specified passing grade limit. The policy raises a big question, that the government is looking for qualified and competent employees, or is the government only looking for employees to fill the vacancy? If it is true that the government is looking for qualified and competent employees, the government should not reduce the passing grade limit that has been set previously. This policy shows that the government pays little attention to the competencies of the employees that they recruited.

The development of the times, the challenges in the selection and recruitment process are increasingly complex. Among them is, how through the selection and recruitment process, an organization gets candidates for future potential, not only for 
current skills. Future potential in the recruitment process is how an organization looking for candidates who have the ability to deal with changing times. However, public organizations today, usually only looking for candidates with current skill criteria or employees who only have the ability to meet current needs, in other words, the short-term ability of an employee. In fact, organizations that only see employees for current needs will be difficult to deal with change. Therefore, future potential candidates are needed to be ready, fast, and responsive in dealing with change.

The second problem that concerns the researcher is the bias of the selection team's assessment in the interview process. The interview is a crucial stage in an employee selection process. In this stage, the selectors can directly assess prospective employees. Prospective employees are also required to show their best performance in the interview process. However, the interview process was filled with bias in the evaluation team's selection. The existence of a biased assessment can make the prospective employees who are competent and qualified will lose competitiveness with ordinary prospective employees. For this reason, a new breakthrough is needed in the 2018 Recruitment and SelectionCivil Servant interview process to overcome this assessment bias.

Another case with South Korea. The South Korean government has reformed human resources so that civil services in South Korea can be more responsive and accountable to the public. One type of human resource reform, is the new employee recruitment system (Kim P. S., 2000). The South Korean government is now considering drastic changes to the civil service exam. As a way to diversify recruitment tools, internationally recognized English language tests and talent methods will be used in the form of the Public Service Aptitude Test (PSAT). Also, intensive interviews will be used to test the applicant's actual work capacity in the form of a blind interview.

\section{Metodhology}

The purpose of writing this article is to discuss the problems in the 2018 recruitment and selection of civil servantand the ideal concept of a recruitment and selection process in public organizations. By using a case study approach to explore issues, problems, or events to be able to understand the problem well (Creswell, 2015). To obtain data, researchers conducted un-depth interviews with 6 participants. Which were divided to, 3 speakers were 
participants who did not qualify for the 2018 recruitment and selection of civil servants; and 3 people were participants who passed the 2018 recruitment and selection of civil servants. In the case study approach, researchers cannot rely on just one data, because it will not be enough to develop a deep understanding of a case. Therefore, to help analyzing the case that researchers found, researchers conducted a literature review study on the ideal recruitment and selection conducted by a public organization to get qualified, competent, and human resources following organizational goals. A literature review is a way to show knowledge about a particular field of study, including theories, phenomena, and methods, and provide a new framework (Randolph, 2009). In a literature review study, researchers gather theories and findings from existing studies, to analyze the findings in case studies.

\section{Discussion}

\section{The Problems of the 2018 Recruitment and Selection of Civil Servants}

In this subchapter, the author will write about the problems that occur during the process of the recruitment and selection of civil servants 2018 in Indonesia. Among the common problems that occur in the field are the availability of facilities and infrastructure, especially the availability of computers, which are adequate in conducting regional selection. In some regions, in the eastern part of Indonesia, for example, recruitment was only carried out in Makassar City, while other Eastern Indonesia regions were unable to carry out the recruitment and selection process due to the limitations of computer technology.

This causes, the online concept launched by the government is considered to be less than optimal. The general purpose of the online process is actually how a person can access something from wherever he is. However, the limitations of computer infrastructure, making the applicants must travel long distances to be able to follow the selection process. In fact, in several Ministries/Institutions, requiring participants to take a Computer Based Test (CBT) based on Basic Competency Selection (Seleksi Kompeteni Dasar-SKD) in the Capital City of the Republic of Indonesia, where their office base is located.

Another problem is the problem of the scientific discipline of the participants. For example, the disciplines needed are automotive mechanical engineering, applicants with a concentration in automotive mechanical engineering, can not pass the selection, and are 
immediately eliminated because the applicant's education certificate is not specifically written as automotive engineering but only written as mechanical engineering.

The more specific issues that the author will discuss are the Basic Competency Selection (SKD) and Interview Selection stages in the 2018 recruitment and selection of civil servants

\section{Basic Competency Selection (Seleksi Kompetensi Dasar-SKD)}

The recruitment of civil servants in 2018 is one of the efforts to procure employees made by the government after the moratorium on civil servants acceptance policies. The determination of the needs of civil servants and the implementation of the selection of 2018 civil servants is regulated in the Minister of Administrative Reform and Bureaucratic Reform of the Republic of Indonesia (PAN-RB Ministerial Regulation) No. 36/2018 concerning Criteria for Determining the Needs of Civil Servants and the Implementation of 2018 Civil Servant Candidates. In the Ministry of Administrative Reform and Bureaucratic Reform Regulation, the total allocation of determination of needs for central and regional agencies is 238,015 with details of 51.271 central agencies and 186,744 regional agencies.

The process of recruiting civil servants in 2018 starts from registration, administrative selection, basic competency selection (SKD), field competency selection (SKB), and interviews. The SKD implementation in 2018 uses the same Computer Assisted Test (CAT) system as in 2017. To be able to participate in the further selection, SKD participants must exceed the passing grade that has been determined in the recruitment of 2018 civil servants (Gulo, Kompasiana Beyond Blogging, 2018).

The implementation of the recruitment and selection of civil servants in 2018 in Indonesia has many records that need to be considered to improve the future recruitment and selection of civil servants. These problems include the results of the selection from the second stage of registration of civil servants, namely the Basic Competency Selection (SKD) is very low and quite alarming. Based on data from the 2018 civil service national selection committee, out of $1,724,990$ who took part in the SKD, only 128,236 met the passing grade. This causes many formations that are threatened could not be filled because many test takers do not meet the qualifications. Most of the formation that is threatened are for the position of teachers and health workers (Dharmaningtias, 2018). 
Basic Competency Selection (SKD) is one of the stages of the selection of civil servants. Based on the page menpan.go.id, the SKD implementation uses the Computer Assisted Test (CAT) system. To pass this stage is determined by a passing grade. SKD value weights 40 percent. Each SKD participant must do 100 questions. The questions consisted of 35 questions on the National Insight Test (Tes Karakteristik Pribadi-TWK), 30 questions on the General Intelligence Test (Tes Karakteristik Pribadi-TIU), and 35 questions on the Personal Characteristics Test (Tes Karakteristik Pribadi-TKP).

Following the Ministry of Administrative Reform and Bureaucratic Reform Regulation (PANRB Ministerial Regulation) No. 37 of 2018 concerning the SKD Threshold Value for CPNS Procurement Year 2018, the passing grade is set at a total of 298, with a TKP detail of 143, TIU of 14380 and TWK of 75. Participants who qualify are those who can break the total number and score of each item. If there is a participant who passes one or two components but does not in the others components, then he does not qualified. This condition made the participants who did not pass feel disappointed, and really hoped that the passing grade would belowered so that many could had more chance to pass the selection (Gulo, Kompasiana Beyond Blogging, 2018).

According to the Deputy of Human Resources (HR) Empowerment of the State Apparatus and Bureaucratic Reform, Setiawan Wangsaatmadja, the passing grade for SKD participants from the general lane applicant group was the same as last year. Test takers must understand how many passing grades are needed in each lane, for example, public lane, cumlaude and diaspora (a nation of a child who has a career abroad or a nation who has performed well abroad bearing the name of Indonesia) (Saputri, Tips Pahami Passing Grade Lebih Mudah agar Lolos SKD CPNS 2018, 2018).

Setiawan Wangsaatmaja previously stated that the graduation rate of civil servants in 2018 was only 10 percent. The data was taken after 60 percent of data entered in the SKD exam as of November 13, 2018. This graduation rate is lower than last year which reached 20 percent. Vice President, Jusuf Kalla said there were 1.8 million participants in the selection of civil servants out of a total of four million applicants. However, based on the report of the Ministry of Administrative Reform and Bureaucratic Reform, only around 8 percent or 100 thousand participants passed the SKD test. Even though the government needs 200 
thousand people (Cahyani, Tes CPNS 2018 Banyak yang Gagal, JK Ungkit Mutu Pendidikan, 2018).

The Ministry of Administrative Reform and Bureaucratic Reform, Syafruddin as the CPNS National Selection Committee will announce a new passing grade. This policy was adopted to address the number of CPNS selection exam participants who did not pass the passing grade in the basic competency selection (SKD) stage. Therefore, the passing grade will be lowered. Head of Ministry of Administrative Reform and Bureaucratic Reform, Mohammad Ridwan said the proposed reduction in passing grade for SKD test was also discussed at the National Selection Committee meeting.

Ridwan explained, the proposal came from various parties, ranging from the Ombudsman; Ministry of Research, Technology and Higher Education of the Republic of Indonesia; Ministry of Education and Culture; and various ministries and other institutions. Besides, the proposal is to prevent a vacancy in formations that are considered vital such as teachers, doctors, and technical staff. Ridwan described the failure of applicants to meet the passing grade for eastern Indonesia as much as 90 percent, 70 percent for central Indonesia, 50 percent for western Indonesia, while 12 percent in central Ministries/Institutions (Rambu, Menpan Akan Turunkan Passing Grade, 2018).

Ministry of Administrative Reform and Bureaucratic Reform Ministry applies a ranking system as an alternative to the SKD test graduation criteria for civil servants selection participants. The system was implemented because of the limited number of the 2018 civil servants' graduation participants and the disparity in graduation results between regions that had the potential to not fulfilled the needs/formations. For the implementation of the system, Minister of Ministry of Administrative Reform and Bureaucratic Reform, Syafruddin has signed Minister of Ministry of Administrative Reform and Bureaucratic Reform Regulation No. 61/2018 concerning Optimization of Fulfillment/Formation of Civil Servants in the Selection of Civil Servants in 2018. The new rules regarding the ranking system are set not to change or cancel the previous regulation, but to strengthen the Minister of Ministry of Administrative Reform and Bureaucratic Reform Regulation No. 37 of 2018 concerning Passing Grade SKD Procurement of Civil Servants 2018.

In the Ministry of Administrative Reform and Bureaucratic Reform Regulation Number 61/2018 it is emphasized, 2018 civil servant selection participants who follow the 
SKD can proceed to the SKB stage with the condition that SKD participants meet the threshold value based on PAN-RB Ministerial Regulation Number 37 of 2018 and SKD participants does not meet the threshold value but has the best ranking of the cumulative SKD figures governed by this Ministerial Regulation.

This provision applies if there are no SKD participants who meet the threshold value based on Ministry of Administrative Reform and Bureaucratic Reform Regulation No. 37 Year 2018 on the requirements/formations that have been determined, or the number of SKD participants who have not met the threshold value based on the Ministerial Regulation No. $37 / 2018$ is to fulfill the required amount of allocation/formation. This system is expected to filter more employees according to the 2018 civil servant formation needs (Dharmaningtias, 2018).

\section{Interview}

Other problems that received less attention from the public in Recruitment and Selection of Civil Servant 2018 are about the subjectivity of the selection organizer, especially in the interview selection process, and the tendency of the government that is not futuristic, namely the government only focuses on finding employees with the ability and expertise in accordance with the needs At present organizations, the government does not pay attention to how the competency needs of workers will be needed in the future (future skills).

The availability of civil servants candidate participant data held by the selectors in the interview process encourages the interviewer to have a first impression on the selection participants, such as information from where the participants came from, or the latest educational background information from the selected participants. A participant who has completed his education at one of the leading universities in Indonesia will usually get a plus point from the selection team. While other participants who completed their education at universities that are not well-known, tend not to get a plus point. Besides, an important question from the author is, how does the government as the organizer of the 2018 Selection of Civil Servant ensure that the interviewer has good qualifications to select participants? It is deemed necessary that the organizers of 2018 recruitment and selection of civil servants have competency standards that must be possessed by the interviewer to avoid the subjectivity of the assessment. 


\section{Result}

\section{Future Potential Skills}

Civil Servants are the basis for implementing reforms in achieving good governance to carry out government tasks and development tasks to achieve aprosperous society (Akny, 2014). Until now, the recruitment and selection of Civil Servants in Indonesia are still focused on the realization of good governance. As stated in Government Regulation No. 11/2017 concerning Management of Civil Servants, that Management of Civil Servants is the management of civil servants to produce civil servants who are professional, have basic values, professional ethics, free from political intervention, free from corrupt practices, collusion, and nepotism.

As a step towards realizing clean, competent, and serving Civil Servants, every Civil Servant must have basic competencies and field competencies following the demands of his position and role as government administrators and community service. Through Ministry of Administrative Reform and Bureaucratic Reform Regulation No. 37/2018 concerning Passing Grade for Basic Competency Selection for Procurement of Prospective Civil Servants in 2018, the government regulates the threshold value of Basic Competency Selection to produce qualified and competent civil servants.

However, the results of the SKD test are very low and quite alarming. Then the Ministry of Administrative Reform and Bureaucratic Reform adopted a ranking system as an alternative to the SKD passing criteria for civil servant selection participants. With this policy, it can filter out employees according to the needs of the 2018 civil servant formation. This policy indicates that the government is less committed in the effort to recruit qualified and competent employees. The government needs to identify what skills will be lost and also anticipate how future labor needs may change (Hays, Kearney, \& Coggburn, 2009). Therefore, the government needs to change the employee recruitment system with the concept of future potential skills.

The concept of future potential can be used to overcome public organizations that tend to look for current skill employees. One effort that can be done to strengthen the concept of future potential is by conducting a foreign language test for each prospective employees. Tests that can be applied in Indonesia are the Test Of English Foreign Language (TOEFL) and the Test Of English for International Communication (TOEIC). Learning from 
South Korea, proficiency in English is a qualification that is demanded in both the public and private sectors in South Korea, because the world becomes a borderless community through globalization and information. Such standardized tests have become a popular element for evaluating practical English language proficiency in the private and public sectors of the Korean state (Kim P. S., 2000).

To develop and manage an organization, especially in the field of public service, an organization needs to develop and manage employees who can think, lead and act from a global perspective and global skills (Kim P. S., 1999). Because in the era of globalization, it requires a progressive transformation of thinking on a public problem. In the Recruitment and Selection of Civil Servants 2018, not all Ministries/Institutions require prospective applicants to include the TOEFL test results.

Based on the writer's observation, compiled from (Arnani, Kompas.com, 2018), there are only 6 Ministries/Institutions that require foreign language skills, especially English. Among them: the Ministry of Energy and Mineral Resources, the Ministry of Foreign Affairs, the State Personnel Agency, the Ministry of Administrative Reform and Bureaucratic Reform, and the Ministry of Public Works and Public Housing. Therefore, it is hoped that in the future all Ministries/Institutions in Indonesia require prospective applicants to include the results of English language proficiency tests, such as TOEFL and TOEIC and the like as an effort to improve the international competitiveness of public employees in Indonesia.

In addition to including the results of English proficiency tests, it is better for prospective employees who have passed the interview stage, to take part in an English interview session. Of course, it is necessary to build English language skills from the employees who are already working. The importance of civil servants mastering English, because this international language is the language of business that is used in the world of commerce. By mastering English, the quality and capacity of civil servants within the government will improve. The increase in human resources is something that is not negotiable in the face of the Asean Economic Community (AEC) era and the era of globalization. Because AEC is an era where the rotation of goods and services easily goes in and out of and to Indonesia quickly (Anwar, PNS Jatim Wajib Mahir Bahasa Inggris, 2014). 


\section{Blind Interviews}

Based on the explanation in the previous point, it was found that the problem of 2018 recruitment and selection of civil servant in Indonesia which became the focus of the writer, was the subjectivity of interviewing prospective employees and the orientation of Indonesian public organizations that only focus on finding employees to meet current organizational needs (current skills). To reduce the level of objectivity of the interviewer, Indonesia recruitmen process could adapt the concept of blind interviews that have been applied in South Korea, both in public and private sector organizations (Hyun-Ju, 2017). The South Korean government is now considering drastic changes to the civil service exam. As a way to diversify recruitment tools, internationally recognized English language tests and talent methods will be used in the form of the Public Service Aptitude Test (PSAT). Besides, intensive interviews will be used to test the applicant's actual work capacity in the form of a blind interview. The interview panel consisting of several executives holding directorgeneral positions in central institutions, together with professors of public affairs, conduct interviews. Interviews conducted by the Korean government are blind interviews with stimulation exercises or discussion sessions.

Interviewers are not given background data or letters of recommendation from interviewees. In this way, they will evaluate applicants on performance alone, not affected by any biases or halo effects caused by background data on prospective employees. Blind interviews are also intended to dispell favoritism that has traditionally marked the selection process. Such favoritism extends from blood-based nepotism to broader favoritism based on shared educational affiliations (Kim P. S., 2000). In addition to favoritism, blind interviewing can also eliminate interviewer discrimination from prospective employees being interviewed. Discrimination often occurs like racial discrimination, for example, the assumption that Javanese people are delicate and polite, while Ambonese is hard and always fiery people. Other discrimination for example about gender. The general public perception is that men can work faster than women. To eliminate gender discrimination, the Government of Norway has set gender quotas for positions in public administration (Laegreid \& Wise, 2007). This is a form of the Norwegian Government's efforts to expand diversity and representation. 
Interview selection is one of the most crucial selection stages in the recruitment and selection process for prospective employees of an organization. In this stage, the competency of prospective employees will be tested directly by the internal employees of the organization and third parties trusted by the organization. However, interview selection itself has become one of the most commonly used recruitment methods which is considered an unfair stage in employee recruitment exams in China (Zhang, Xu, \& Zhang, 2015), because in this process, selectors have full dominance to determine whether a prospective employee is worthy to be an employee of an organization or not. Because it has full dominance over a decision, the element of subjectivity in this process is very high. To eliminate discrimination and subjectivity, the recruitment process of several organizations, both public and private, has adopted the concept of blind interviews, such as the Deloitte Company, Ernst \& Young, Victoria Police Department, and Westpac Bank (Feldmann, 2018). The selection decision will only be based on how they evaluate prospective employees. Problems will arise if the selectors cannot work professionally.

A blind interview means that the details of a prospective employee's personal data are released from the registration form, so the interview selection team can only consider the competency, skills and work experience of the prospective employee. Since 2017 (Hyun-Ju, 2017), the South Korean Government has implemented the system of blind recruitment in the public service sector and extended it to private companies to ensure competition in the recruitment and selection process runs as fairly as possible and can recruit the right candidates and qualified. The South Korean government prohibits the selection team from requesting prospective employee personal data, such as family relations, educational background, place of birth, and physical attributes in the selection process. Such personal data is released so that the selection team focuses on considering the professionalism of prospective employees, their skills and work experience. Attaching photos to forms will also be prohibited. This is done so that people who have good competence are not sidelined because of discrimination that comes from academic or other backgrounds. In the blind interview, the selection team will focus on evaluating the prospective employee's work experience and qualifications that are relevant to the needs of the organization. Information about physical abilities and educational background should only be asked in certain cases relevant to employment. 
To eliminate discrimination and subjectivity of selectors in the recruitment and selection interview process, a blind interview is one of the efforts that can be done. With a blind interview, it shows that the organization has a strong commitment to recruiting prospective employees who focus on the competencies and qualifications determined by the organization (Rinne, 2018). If the selection and recruitment decisions of employees are based on the competencies and qualifications of prospective employees the results will automatically be in line with the organization's goals to recruit the most competent employees, so that later it will help the organization in achieving organizational goals. Besides, the existence of a blind interview can improve the atmosphere of competition between prospective employees. Prospective employees will try their best in the interview process to be able to show their competence without worrying about discrimination from selectors.

In a blind interview, the selection team will determine a set of competencies and concepts and ask a number of questions for prospective employees (Boyce Recruitment, 2019). A healthy recruitment philosophy means asking right and wise questions (Breaugh \& Starke, 2000), and it is important that the questions should remain focused on work. The questions asked should lead potential employees to explain how they will solve problems in different ways (Miller, 2016). Before the interview, the selection team determines a series of competencies and concepts and raises several issues. Prospective employees are required to provide identifiable responses, both positive and negative (Boyce Recruitment, 2019). This response should be taken into consideration by the selection team.

In conducting a blind interview, there are several problems that can occur including the tendency of organizational culture. It is natural if the organization wants to recruit employees because of the compatibility between employee candidates with the culture in the organization. In the recruitment and selection process, the organization will look for prospective employees who lead to hiring prospective employees who look the same, act the same, think the same, and come from the same background (Feldmann, 2018). The result is a homogeneous culture within the organization which makes it difficult for organizations to develop because their prospective employees must work in accordance with organizational culture. In addition, blind interviews are expensive to implement and may not be costefficient for an organization (Boyce Recruitment, 2019). Small organizations may still be 
more cost-effective to carry out blind interviews, but large organizations need quite expensive costs in the blind interview process. To overcome cost overruns, organizations can use their internal staff to manage the interview process, but it must be ensured that they have the credibility as selectors.

\section{Conclusion and Limitation}

The recruitment and selection process is an important process for organizational success. Because, in the recruitment and selection process, the organization will look for, choose, and attract competent human resources. The importance of competent human resources in an organization because they will control the other resources in the organization. During this time, the recruitment and selection process of civil servants in Indonesia has been carried out with a merit system. The merit system was first defined as intelligence plus work effort (So, 2015).

This merit-based system emphasizes technical qualifications using processes that analyze work competency and require open application procedures. However, the merit system, which has been running so far, does not work perfectly and leaves several problems. Some problems that arise in the process of recruitment and selection of civil servants in 2018 are about the attitude of the government as the organizer who does not pay attention to the needs of future potential for its employees, and the subjectivity of the selectors at the interview selection stage.

The government feels it is necessary to have standardization for interviewers and implement blind interviews to avoid bias in the evaluation and selection of interviews. Besides, the concept of future potential is expected to be a concern of the government for recruiting employees, bearing in mind that the challenges of public organizations in the future will be more complex, so it is necessary to prepare employees who have the ability and competitiveness to face future challenges.

This article has limitations because it only uses un-depth case study methods and literature review in its writing. So the authors hope for further research that can be done by jumping directly into the field to explore the facts of the recruitment and selection of civil servants deeper so that it can produce research that is closer to the actual reality. 


\section{References}

\section{Book}

Boselie, P., \& Thunnissen, M. (2015). Talent Management in the Public Sector: Managing Tensions and Dualities. Inggris: Oxford Handbooks Online.

Creswell, J. W. (2015). Penelitian Kualitatif \& Desain Riset (3rd Esition ed.). Yogyakarta: Pustaka Pelajar.

Education Development Center. (2002). Srvice-learning Satisfies Young People's Desire for Public Service. Education Development Center.

Hays, S., Kearney, R., \& Coggburn, J. (2009). Public Human Resources Management: Problems and Prospects. London: Longman.

Merit System Protection Board (MSPB). (2008). Attracting the Next Generation: A Look at Federal Entry-level New Hires. Washington DC: MSPB.

Sunyoto, D. (2012). Manajemen Sumber Daya Manusia. Yogyakarta: CAPS.

\section{Journal article}

Berman, E. M., Bowman, J. S., West, J. P., \& Wart, M. R. (2010). Human Resource Management in Public Service: Paradoxes, Processes, and Problem. California: SAGE Publications, Inc.

Breaugh, J., \& Starke, M. (2000). Research on Employee Recruitment: So Many Studies, So Many Remaining Questions. Journal of Management, 26 (3), 405-434.

Ishii, R., Rohitarachoon, P., \& Hossai, F. (2013). HRM Reform in Decentralised Local Government: Empirical Perspectives on Recruitment and Selection in the Philippines and Thailand. Asian Journal of Political Science, 21 (3), 249-267.

Kim, P. S. (1999). Globalization of Human Resource Management: A Cross Cultural Perspective for The Public Sector. Public Personnel Management , 2B (2), 227-24.

Kim, P. S. (2000). Human Resources Management Reform in The Korean Civil Service. Administrative Theory \& Praxis , 22 (2), 326-344.

Laegreid, P., \& Wise, L. R. (2007). Reforming Human Resource Management in Civil Service Systems: Recruitment, Mobility, and Representativeness. In J. N. Raadschelders, The Civil Service in The 21st Century (pp. 169-182). Milan: Macmillan Publisher Limited.

Lavigna, R. J., \& Hays, S. W. (2004). Recruitment and Selection of Public Workers: An International Compendium of Modern Trends and Practices. Public Personnel Management Journal (33), 237-253. 
Mirela, \& Voicu, C. (2014). Using Online Questionnaires in The Employee Recruitment Activity. Procedia Social and Behavioral Sciences , 124, 34-42.

Osoian, C., \& Zaharie, M. (2014). Recrutmen for Competencies in Public and Private Sectors. Transylvania Review of Administrative Sciences (41E), 129-145.

Ozzbilgin, M., \& Tatli, A. (2011). Mapping out the field of equality and diversity: Rise of individualism and voluntarism. Human Relations, 1229-1253.

Randolph, J. J. (2009). A Guide to Writing the Dissertation Literature Review. Journal of Pactical Assessment, Research and Evaluation , 14 (13), 1-13.

Rinne, U. (2018). Anonymous Job Applications And Hiring Discrimination. Iza World of Labour , 42.

Akny, A. B. (2014). Mewujudkan Good Governance melalui Reformasi Birokrasi di Bidang SDM Aparatur untuk Peningkatan Kesejahteraan Pegawai. Jejaring Administrasi Publik, 416-427.

Anwar, M. (2014, November 30). PNS Jatim Wajib Mahir Bahasa Inggris. Retrieved September 25, 2019, from surya.co.id: https://surabaya.tribunnews.com/2014/11/30/pns-jatimwajib-mahir-bahasa-inggris

Anwar, M. (2014, 11 30). PNS Jatim Wajib Mahir Bahasa Inggris. Retrieved 09 25, 2019, from surya.co.id: https://surabaya.tribunnews.com/2014/11/30/pns-jatim-wajib-mahirbahasa-inggris

Arnani, M. (2018, October 11). Kompas.com. Retrieved 10 7, 2019, from Kompas.com: https://nasional.kompas.com/read/2018/10/11/19283281/cpns-2018-capai-4-jutapelamar-ini-jumlah-pendaftar-dari-tiap-formasi?page=all

Arnani, M. (2018, September 20). Kompas.com. Retrieved October 2, 2019, from Kompas.com: https://nasional.kompas.com/read/2018/09/20/12555931/ini-6-kementerianlembagayang-syaratkan-toefl-bagi-pelamar-cpns-2018?page=all

Berman, E. M., Bowman, J. S., West, J. P., \& Wart, M. R. (2010). Human Resource Management in Public Service: Paradoxes, Processes, and Problem. California: SAGE Publications, Inc.

Boselie, P., \& Thunnissen, M. (2015). Talent Management in the Public Sector: Managing Tensions and Dualities. Inggris: Oxford Handbooks Online.

Boyce Recruitment. (2019, March 3). Boyce Recruitment. Retrieved October 5, 2019, from Boyce Recruitment Web Site: https://www.boycerecruitment.co.uk/blind-interviews/

Breaugh, J., \& Starke. (2002). Research on Employee Recruitment: So Many Studies, So Many Remaining Questions. Journal Of Management, 26(3), 405-435. 
Breaugh, J., \& Starke, M. (2000). Research on Employee Recruitment: So Many Studies, So Many Remaining Questions. Journal of Management, 26(3), 405-434.

Cahyani, D. R. (2018, November 15). Tes CPNS 2018 Banyak yang Gagal, JK Ungkit Mutu Pendidikan. Retrieved October 04, 2019, from tempo.co: https://bisnis.tempo.co/read/1146614/tes-cpns-2018-banyak-yang-gagal-jk-ungkitmutu-pendidikan

Cahyani, D. R. (2018, 11 15). Tes CPNS 2018 Banyak yang Gagal, JK Ungkit Mutu Pendidikan. Retrieved 10 04, 2019, from tempo.co: https://bisnis.tempo.co/read/1146614/tes-cpns2018-banyak-yang-gagal-jk-ungkit-mutu-pendidikan

Creswell, J. W. (2015). Penelitian Kualitatif E Desain Riset (3rd Esition ed.). Yogyakarta: Pustaka Pelajar.

Dharmaningtias, D. S. (2018). Nilai Ambang Batas dalam Penerimaan CPNS 2018. Pusat Penelitian Badan Keahlian DPR RI, 25-30.

Education Development Center. (2002). Srvice-learning Satisfies Young People's Desire for Public Service. Education Development Center.

Feldmann, J. (2018, April 3). Forbes. Retrieved October 4, 2019, from Forbes.com: https://www.forbes.com/sites/forbeshumanresourcescouncil/2018/04/03/the-benefitsand-shortcomings-of-blind-hiring-in-the-recruitment-process/\#660aa7d838a3

Gulo, Y. (2018, November 17). Kompasiana Beyond Blogging. Retrieved October 4, 2019, from Kompasiana.com: https://www.kompasiana.com/yupiter/5beeab90aeebe169c44d9e05/rendahnyakelulusan-cpns-2018-mencari-siapa-yang-salah?page=all

Gulo, Y. (2018, 11 17). Kompasiana Beyond Blogging. Retrieved 10 4, 2019, from Kompasiana.com: https://www.kompasiana.com/yupiter/5beeab90aeebe169c44d9e05/rendahnyakelulusan-cpns-2018-mencari-siapa-yang-salah?page=all

Hays, S., Kearney, R., \& Coggburn, J. (2009). Public Human Resources Management: Problems and Prospects. London: Longman.

Hyun-Ju, O. (2017, July 5). The Korea Herald. Retrieved October 5, 2019, from The Korea Herald Web Site: http://www.koreaherald.com/view.php?ud=20170705000768

Ishii, R., Rohitarachoon, P., \& Hossai, F. (2013). HRM Reform in Decentralised Local Government: Empirical Perspectives on Recruitment and Selection in the Philippines and Thailand. Asian Journal of Political Science, 21(3), 249-267. 
Kim, P. S. (1999). Globalization of Human Resource Management: A Cross Cultural Perspective for The Public Sector. Public Personnel Management, 2B(2), 227-24.

Kim, P. S. (2000). Human Resources Management Reform in The Korean Civil Service. Administrative Theory \& Praxis, 22(2), 326-344.

Laegreid, P., \& Wise, L. R. (2007). Reforming Human Resource Management in Civil Service Systems: Recruitment, Mobility, and Representativeness. In J. N. Raadschelders, The Civil Service in The 21st Century (pp. 169-182). Milan: Macmillan Publisher Limited.

Lavigna, R. J., \& Hays, S. W. (2004). Recruitment and Selection of Public Workers: An International Compendium of Modern Trends and Practices. Public Personnel Management Journal(33), 237-253.

Merit System Protection Board (MSPB). (2008). Attracting the Next Generation: A Look at Federal Entry-level New Hires. Washington DC: MSPB.

Miller, C. C. (2016, February 26). New York Times Magazine. Retrieved October 4, 2019, from Nytimes Web Site: https://www.nytimes.com/2016/02/28/magazine/is-blind-hiringthe-best-hiring.html

Mirela, \& Voicu, C. (2014). Using Online Questionnaires in The Employee Recruitment Activity. Procedia Social and Behavioral Sciences, 124, 34-42.

Osoian, C., \& Zaharie, M. (2014). Recrutmen for Competencies in Public and Private Sectors. Transylvania Review of Administrative Sciences(41E), 129-145.

Ozzbilgin, M., \& Tatli, A. (2011). Mapping out the field of equality and diversity: Rise of individualism and voluntarism. Human Relations, 1229-1253.

Rambu, B. (2018, November 14). Menpan Akan Turunkan Passing Grade. Retrieved October 04, 2019, from victorynews.id: https://www.victorynews.id/menpan-akan-turunkanpassing-grade/

Rambu, B. (2018, 11 14). Menpan Akan Turunkan Passing Grade. Retrieved 10 04, 2019, from victorynews.id: https://www.victorynews.id/menpan-akan-turunkan-passing-grade/

Randolph, J. J. (2009). A Guide to Writing the Dissertation Literature Review. Journal of Pactical Assessment, Research and Evaluation, 14(13), 1-13.

Rinne, U. (2018). Anonymous Job Applications And Hiring Discrimination. Iza World of Labour, 42.

Saputri, M. (2018, October 27). Tips Pahami Passing Grade Lebih Mudah agar Lolos SKD CPNS 2018. Retrieved October 04, 2019, from tirto.id: https://tirto.id/tips-pahami-passinggrade-lebih-mudah-agar-lolos-skd-cpns-2018-c8HR 
Saputri, M. (2018, 10 27). Tips Pahami Passing Grade Lebih Mudah agar Lolos SKD CPNS 2018. Retrieved 10 04, 2019, from tirto.id: https://tirto.id/tips-pahami-passing-grade-lebihmudah-agar-lolos-skd-cpns-2018-c8HR

So, B. W. (2015). Exam-Centered Meritocracy in Taiwan: Hiring by Merit or Examination? Australian Journal of Public Administration, 74(3), 312-323.

Sunyoto, D. (2012). Manajemen Sumber Daya Manusia. Yogyakarta: CAPS.

Zhang, Y., Xu, B., \& Zhang, J. (2015). Impact of Procedural Characteristic on Justice Perceptions of Chinese Civil Service Candidates. Public Personnel Management Journal, 44(4), 543-558.

\section{Newspaper article on website}

Anwar, M. (2014, November 30). PNS Jatim Wajib Mahir Bahasa Inggris. Retrieved September 25, 2019, from surya.co.id: https://surabaya.tribunnews.com/2014/11/30/pns-jatimwajib-mahir-bahasa-inggris

Arnani, M. (2018, October 11). Kompas.com. Retrieved 10 7, 2019, from Kompas.com: https://nasional.kompas.com/read/2018/10/11/19283281/cpns-2018-capai-4-jutapelamar-ini-jumlah-pendaftar-dari-tiap-formasi?page=all

Arnani, M. (2018, September 20). Kompas.com. Retrieved October 2, 2019, from Kompas.com: https://nasional.kompas.com/read/2018/09/20/12555931/ini-6-kementerianlembagayang-syaratkan-toefl-bagi-pelamar-cpns-2018?page=all

Boyce Recruitment. (2019, March 3). Boyce Recruitment. Retrieved October 5, 2019, from Boyce Recruitment Web Site: https://www.boycerecruitment.co.uk/blind-interviews/

Cahyani, D. R. (2018, November 15). Tes CPNS 2018 Banyak yang Gagal, JK Ungkit Mutu Pendidikan. Retrieved October 04, 2019, from tempo.co: https://bisnis.tempo.co/read/1146614/tes-cpns-2018-banyak-yang-gagal-jk-ungkitmutu-pendidikan

Feldmann, J. (2018, April 3). Forbes. Retrieved October 4, 2019, from Forbes.com: https://www.forbes.com/sites/forbeshumanresourcescouncil/2018/04/03/the-benefitsand-shortcomings-of-blind-hiring-in-the-recruitment-process/\#660aa7d838a3

Gulo, Y. (2018, November 17). Kompasiana Beyond Blogging. Retrieved October 4, 2019, from Kompasiana.com:

https://www.kompasiana.com/yupiter/5beeab90aeebe169c44d9e05/rendahnyakelulusan-cpns-2018-mencari-siapa-yang-salah?page=all 
Hyun-Ju, O. (2017, July 5). The Korea Herald. Retrieved October 5, 2019, from The Korea Herald Web Site: http://www.koreaherald.com/view.php?ud=20170705000768

Miller, C. C. (2016, February 26). New York Times Magazine. Retrieved October 4, 2019, from Nytimes Web Site: https://www.nytimes.com/2016/02/28/magazine/is-blind-hiring-thebest-hiring.html

Rambu, B. (2018, November 14). Menpan Akan Turunkan Passing Grade. Retrieved October 04, 2019, from victorynews.id: https://www.victorynews.id/menpan-akan-turunkanpassing-grade/

Saputri, M. (2018, October 27). Tips Pahami Passing Grade Lebih Mudah agar Lolos SKD CPNS 2018. Retrieved October 04, 2019, from tirto.id: https://tirto.id/tips-pahami-passinggrade-lebih-mudah-agar-lolos-skd-cpns-2018-c8HR

\section{Website document}

Akny, A. B. (2014). Mewujudkan Good Governance melalui Reformasi Birokrasi di Bidang SDM Aparatur untuk Peningkatan Kesejahteraan Pegawai. Jejaring Administrasi Publik, 416-427.

Dharmaningtias, D. S. (2018). Nilai Ambang Batas dalam Penerimaan CPNS 2018. Pusat Penelitian Badan Keahlian DPR RI , 25-30. 